\title{
混合散剤の分包ロスと逃飛率および安息角との関係*1
}

\author{
住田克己, 若林慶子, 佐藤和代, 勝田秀夫, 古市勝久*2 \\ 三重大学医学部付属病院薬剮部*2

\section{Relationship Between the Loss in Weight on Dividing and Dustability or Angle of Repose of Compound Powders*1}

\author{
Katsumi SMida, KeIKo WAKabayaShI, KaZUYo Sato, \\ HIDEO KATSUTA and KATSUHISA FURUICHI ${ }^{* 2}$ \\ Department of Pharmacy, Mie University Hospital*2
}

\begin{abstract}
Two kinds of powders with different physical properties were chosen to examine the relations between the angle of repose, dispersibility and the loss in weight on dividing and packaging. The loss in weight on dividing of the two kinds of powders, when mixed, may depend largely on their physical properties. Actually, the relation between dispersibility and the loss in weight, though largely depending on physical properties of powders, generally fluctuated in proportion to the mixing ratio. The angle of repose showed a tendency to fluctuate in proportion to the mixing ratio. But when two kinds of powders with different physical properties are mixed, it is difficult to measure the angle of repose because they separate before measuring. Therefore, it is impossible to observe minutely the relation between the angle of repose and the loss in weight on dividing.
\end{abstract}

散剤自動分包機使用時の，分包重量減少率におよぼす 因子および問題点について，第 1 報1)，第 2 報2)では，散 剤の温度, 湿度, 水分率, 逃飛率および安息角との関係 を検討し若干の測定結果を報告した。

しかしながら前回までの報告内容 ${ }^{1,2)}$ は，いずれも散 剂単味分包時における諸因子の影響に関する観察結果で あり，実務上での例数は非常に少ない，実際の調剤業務 における散鼡調阂は散剤の単味処方だけでなく，2 種あ るいはそれ以上の混合調剤が主である．分包ロスを論ず るにあたっては，多種混合分包時に淤る分包口スの検 討が必要であると考兄，今回は，2 種類の散剤混合時に 护ける分包口スについて測定を行ない，分包口スに主に 影響を扣よぼすと考兄られる逃飛率，安息解との関係に ついても若干の知見を得たので報告する.

\section{実 験 方 法}

\section{1 検体について}

a） 2 種混合散剂の実際処方調剂時における分包口ス

*1 本報を散凧の分包重量減少率におよばす影響（第 3 報）上する. 東海薬剤師会第 8 回学術大会（津, 1975年) で発表

*2 津市江戸橋 2 丁目 $174 ; 174$ Edobashi 2-chome, Tsu, 514 Japan.
を調べるため, 当院発行の外来処方せんのらち, 比較的 頻繁に処方されると考えられる処方せんをえらび，調風 室に平常装置されている装置瓶中の散剤を使用し, 平常 調剂業務の重量監查時の分包口スを測定した。

b） 2 種混合散剂の分包口スの変動を測定するにあた っては, 前回の報告1,2) と同様の考方方で, 市販の各種 散剤のらち物理的性質の異なる 3 種の剂形を選んだ.す なわち, 飛散性, 吸湿性の粉末薬としては, SM散,ル チン散, 乳酸カルシウム, 微細粒の粉末薬として Lac B, 顆粒剤としてコランチル顆粒を選び実験に供した。

\section{2 㭘体の測定条件}

室温 $23 \sim 24^{\circ}$, 湿度 $67 \sim 73 \%$ の条件下の室内で, 実 際の処方調剤時の分包口スの測定, ならびに 2 種混合散 剤の分包口ス, 逃飛率, 安息角の測定を行なった。なお 散剤の混合方法としては，いずれの測定時にも磁製の乳 鉢を使用し，磁製の乳棒で約30回軽く覧找し実験に使用 した。

\section{3 逃飛率, 安息角の測定}

前回の報告 ${ }^{1,2)}$ と同様に, 逃飛率の測定には昭和エン ジニアリング製の逃飛率測定器, 安息角の測定には昭和 エンジニアリング製の安息角測定器を用い，青木らの方

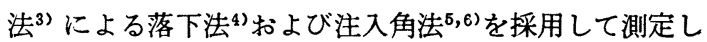


た。

\section{4 分包口スの测定}

前回の報告 ${ }^{1,2)}$ と同様に，小西式自動分割分包機 727 型（日立 CV140 吸引器付）を使用し，当院発行の処方 せん調阂時における分包ロスならびに前記散凧の混合時 の分包口スを測定し，前回 ${ }^{1,2)}$ と同様に次式により散放 の分包重量減少率ならびに Total ロスを計算した。

$\mathrm{x} / 15 \times 100=$ 散凧の分包重量減少率

y $/ 15 \times 100=$ Total 分包重量減少率

$\mathrm{x}$ は散斉 $15 \mathrm{~g}$ を分割分包後の減少重量.

$\mathrm{y}$ は散剤 $15 \mathrm{~g}$ を分割分包し，それを開封後の減少重 量.

なお上記の測定にあたっては，各々 5 回ずつ測定し， その平均值をとり検体の分包ロスとした。ただし，実際 の処方調剤時における分包ロスについては 1 回の測定に とどめた。なお，患者が実際に服用する場合に考えられ る Total ロスの測定については，前報1,2) と同様に分 包紙をハサミで開封し，散剤を取り出し秤量し，Total ロスとした。

\section{轺果ならびに考寮}

\section{1 実際姏方調用の工監查時における分包ロス}

当院発行の外来処方せんのうち，2 種混合散剤ででき るだけ剂形・物性の異なったものを選び，日常調剤を行

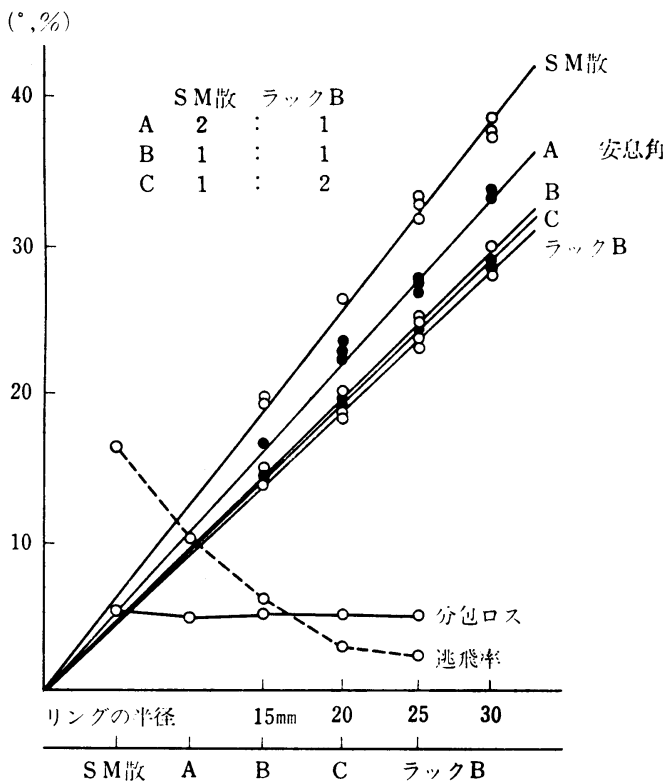

図 1 S M 散, ラックB 混合比と安息角, 逃飛率お よび分包口スの関係

（室温 $23 \sim 24^{\circ}$, 湿度 $67 \sim 73 \%$ )

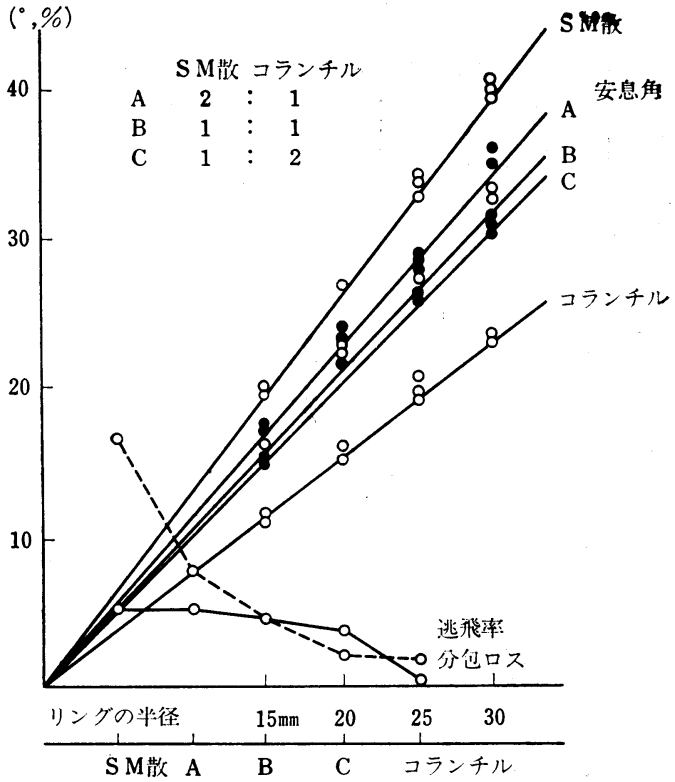

図 2 S M散, コランチル顆粒混合比と安息角, 逃 飛率および分包口スの関係

（室温 23〜24，湿度 $67 \sim 73 \%$ )

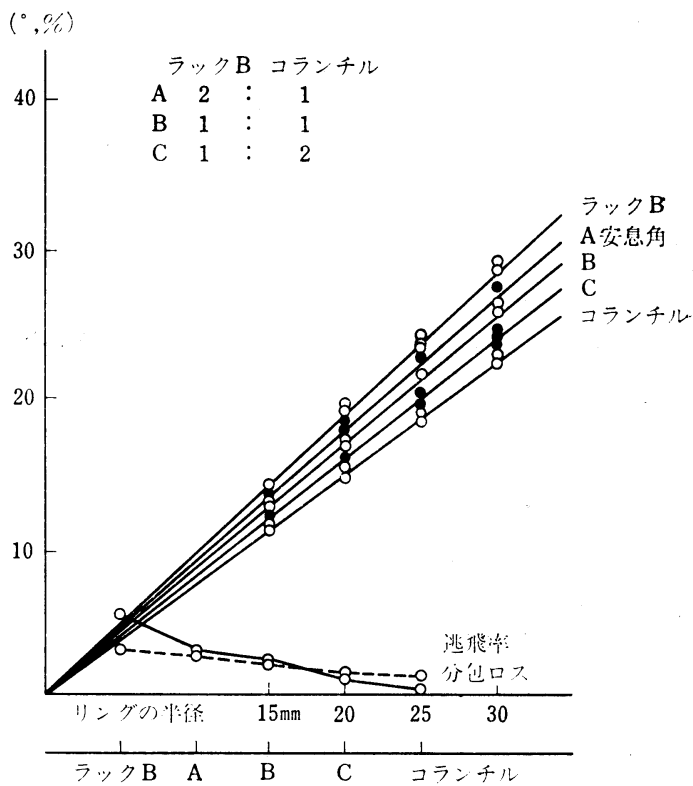

図 3 ラックB，コランチル顆粒混合比と安息角， 逃飛率および分包口スの関保

（室温 $23 \sim 24^{\circ}$, 湿度 $67 \sim 73 \%$ ) 


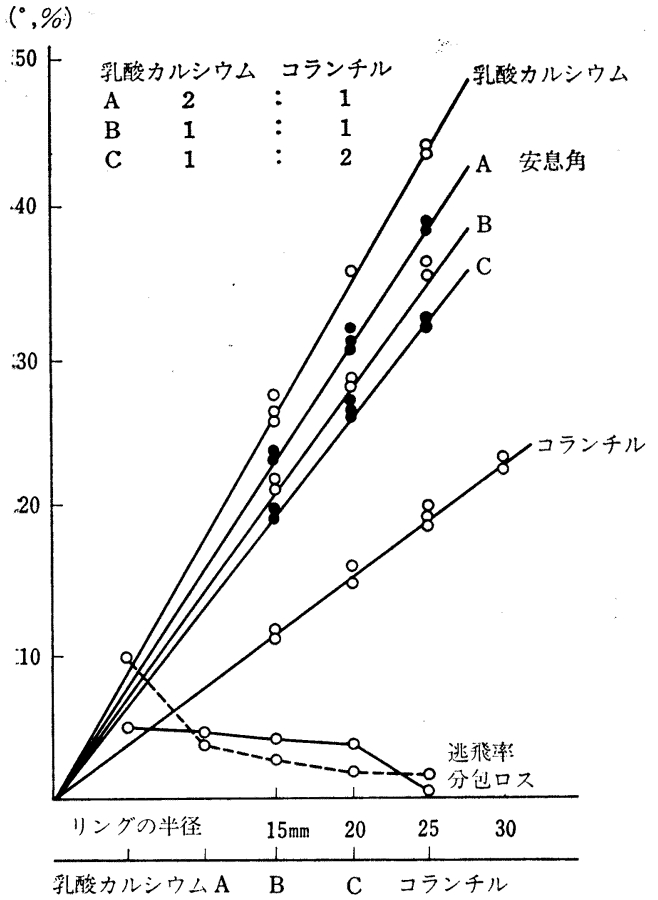

図 4 乳酸カルシウム, コランチル顆粒混合比と安 息角，逃飛率および分包口スの関係

(室温 $23 \sim 24^{\circ}$, 湿度 $67 \sim 73 \%$ )

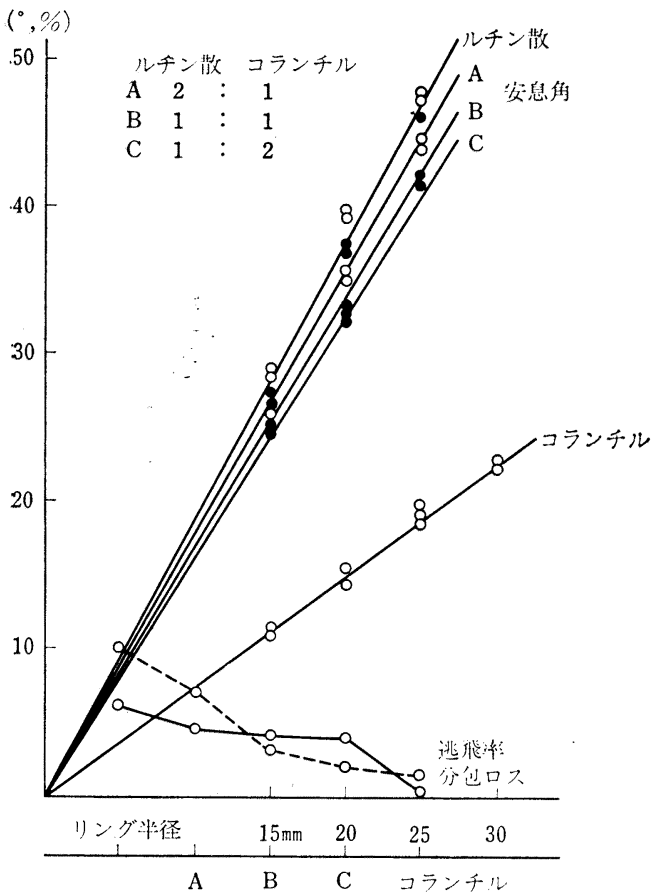

図 5 ルチン散, コランチル顆粒混合比と安息角, 逃飛率および分包口スの関係

(室温 $23 \sim 24^{\circ}$, 湿度 $67 \sim 73 \%$ )
なっている状態に打ける分包ロスを測定した結果を表 1 に示した. 常識的ではあるが，いずれの場合も回転式自 動分割分包機使用の場合は分包口スを 0 にすることは不 可能である. 又, 分包口スの大小は手分割分包が自動分 割分包よりも分包口スが小である。また表 1 の数字から も推定されるように, 分包後分包紙を開封して, 患者が 実際に服用すると考えられる Total ロスはかなり大き

表 1 当院外来処方調剤重量監査時における分包口 不例 (727 型使用分 3.7 日分処方調剂) 室温 $23 \sim 24^{\circ}$, 湿度 $67 \sim 73 \%$

\begin{tabular}{|c|c|c|c|c|}
\hline 処 方 内 & 容 & 手 分 割 & 自動分割 & Total \\
\hline $\begin{array}{l}\text { シノミン } \\
\text { S M散 }\end{array}$ & $\begin{array}{l}2.0 \\
3.0\end{array}$ & $2.00^{\%}$ & 2.40 & 4. 35 \\
\hline $\begin{array}{l}\text { ルチン散 } \\
\text { エビオス }\end{array}$ & $\begin{array}{l}1.0 \\
3.0\end{array}$ & 1.40 & 2.00 & 4.20 \\
\hline $\begin{array}{l}\text { アドナ散 } \\
\text { 酸化マグネシウム }\end{array}$ & $\begin{array}{l}1.0 \\
0.8\end{array}$ & 1.65 & 2.15 & 4.76 \\
\hline $\begin{array}{l}\text { コランチル } \\
\text { ラクトミン末 }\end{array}$ & $\begin{array}{l}4.0 \\
3.0\end{array}$ & 2.00 & 2.25 & 3.50 \\
\hline $\begin{array}{l}\text { トランサミン } \\
\text { パンカル } \mathrm{G}\end{array}$ & $\begin{array}{l}1.5 \\
1.5\end{array}$ & 1.66 & 2.00 & 2.30 \\
\hline $\begin{array}{l}\text { ュランチル } \\
\text { 酸化マグネシウム }\end{array}$ & $\begin{array}{l}4.0 \\
1.0\end{array}$ & 0.28 & 1.05 & 1.30 \\
\hline $\begin{array}{l}\text { ビルスミン末 } \\
\text { パンカルG }\end{array}$ & $\begin{array}{l}2.0 \\
1.5\end{array}$ & 0.82 & 4.00 & 5.30 \\
\hline $\begin{array}{l}\text { アピラコール散 } \\
\text { ガストロピロール }\end{array}$ & $\begin{array}{r}1.5 \\
3.0\end{array}$ & 2.05 & 3.10 & 4.45 \\
\hline
\end{tabular}

表 $2 \mathrm{~S} \mathrm{M}$ 散, ラック B 混合比と安息角, 逃飛率お よび分包ロスの関係 （室温 $23 \sim 24^{\circ}$, 湿度 $67 \sim 73 \%$ )

\begin{tabular}{|c|c|c|c|c|}
\hline \multicolumn{2}{|c|}{ 混合比混合比 } & $\begin{array}{c}S M \text { 散 } \\
0\end{array}$ & 1 & 2 \\
\hline $\begin{array}{c}\text { ラック } \mathrm{B} \\
0\end{array}$ & $\begin{array}{l}\text { 安息角 } \\
\text { 逃 飛 率 } \\
\text { 分包口ス }\end{array}$ & & $\begin{array}{r}52.5 \\
16.5 \\
5.0\end{array}$ & \\
\hline 1 & $\begin{array}{l}\text { 安息角 } \\
\text { 逃 飛 } \\
\text { 分包口ス }\end{array}$ & $\begin{array}{l}43.5 \\
2.50 \\
5.10\end{array}$ & $\begin{array}{r}44.5 \\
5.90 \\
5.05\end{array}$ & $\begin{array}{r}48.0 \\
10.3 \\
4.85\end{array}$ \\
\hline 2 & $\begin{array}{l}\text { 安息角 } \\
\text { 逃 飛 率 } \\
\text { 分包口ス }\end{array}$ & & $\begin{array}{r}44.0 \\
2.80 \\
5.10\end{array}$ & \\
\hline
\end{tabular}


表 $3 \mathrm{~S} \mathrm{M}$ 散, コランチル顆粒混合比と安息角, 逃 飛率および分包口スの関係 (室温 $23 \sim 24^{\circ}$, 湿度 $67 \sim 73 \%$ )

\begin{tabular}{|c|c|c|c|c|}
\hline \multicolumn{2}{|c|}{ 混合比 混合比 } & $\begin{array}{c}\text { SM散 } \\
0\end{array}$ & 1 & 2 \\
\hline $\begin{array}{c}\text { ュランチ } \\
\text { ル顆粒 } \\
0\end{array}$ & $\begin{array}{l}\text { 安息 角 } \\
\text { 逃 飛 } \\
\text { 分包口ス }\end{array}$ & & $\begin{array}{r}52.5 \\
16.5 \\
5.0\end{array}$ & \\
\hline 1 & $\begin{array}{l}\text { 安息 角 } \\
\text { 逃 飛 } \\
\text { 分包口ス }\end{array}$ & $\begin{array}{l}37.0 \\
1.70 \\
0.07\end{array}$ & $\begin{array}{l}46.5 \\
4.20 \\
4.27\end{array}$ & $\begin{array}{l}48.5 \\
7.60 \\
5.00\end{array}$ \\
\hline 2 & $\begin{array}{l}\text { 安息 角 } \\
\text { 逃飛 } \\
\text { 分包口ス }\end{array}$ & & $\begin{array}{l}45.0 \\
2.00 \\
3.65\end{array}$ & \\
\hline
\end{tabular}

表 4 ラック B，コランチル顆粒混合比と安息角, 逃飛率わよび分包口スの関係 （室温 $23-24^{\circ}$, 湿度 $67-73 \%$ )

\begin{tabular}{|c|c|c|c|c|}
\hline & 混 合 比 & $\begin{array}{c}\text { ラック } \mathrm{B} \\
0\end{array}$ & 1 & 2 \\
\hline $\begin{array}{c}\text { コランチ } \\
\text { ル顆粒 } \\
0 \\
0\end{array}$ & $\begin{array}{l}\text { 安息 角 } \\
\text { 逃 飛 } \\
\text { 分包口 }\end{array}$ & & $\begin{array}{l}43.5 \\
2.5 \\
5.10\end{array}$ & \\
\hline 1 & $\begin{array}{l}\text { 安息角 } \\
\text { 逃飛 } \\
\text { 分包口 }\end{array}$ & $\begin{array}{l}37.0 \\
1.70 \\
0.07\end{array}$ & $\begin{array}{l}40.0 \\
1.90 \\
2.00\end{array}$ & $\begin{array}{r}42.0 \\
2.40 \\
2.66\end{array}$ \\
\hline 2 & $\begin{array}{l}\text { 安息角 } \\
\text { 逃飛 } \\
\text { 分包口ス }\end{array}$ & & $\begin{array}{r}38.5 \\
1.70 \\
1.66\end{array}$ & \\
\hline
\end{tabular}

表 5 乳酸カルシウム, コランチル顆粒混合比と安 息角，逃飛率および分包口スの関係 （室温 $23 \sim 24^{\circ}$, 湿度 $67 \sim 73 \%$ )

\begin{tabular}{|c|c|c|c|c|}
\hline \multicolumn{2}{|c|}{ 混合比混合比 } & 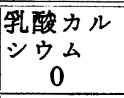 & 1 & 2 \\
\hline \multirow{3}{*}{$\begin{array}{c}\text { ュランチ } \\
\text { ル顆粒 } \\
0\end{array}$} & 安息角 & \multicolumn{3}{|c|}{60.0} \\
\hline & 逃飛 率 & \multicolumn{3}{|c|}{9.5} \\
\hline & 分包口ス & \multicolumn{3}{|c|}{4.60} \\
\hline \multirow{3}{*}{1} & 安息角 & 37.0 & 54.0 & 57.0 \\
\hline & 逃飛率 & 1.70 & 2.50 & 3.70 \\
\hline & 分包口ス & 0.07 & 4.40 & 4.50 \\
\hline \multirow{3}{*}{2} & 安息 角 & \multicolumn{3}{|c|}{52.0} \\
\hline & 逃飛 率 & \multicolumn{3}{|c|}{2.00} \\
\hline & 分包口ス & \multicolumn{3}{|c|}{4.00} \\
\hline
\end{tabular}

表 6.ルチン散, コランチル顆粒混合比と安息角逃 飛率および分包口スの関係 （室温 $23 \sim 24^{\circ}$, 湿度 $67 \sim 73 \%$ )

\begin{tabular}{|c|c|c|c|c|}
\hline \multicolumn{2}{|c|}{ 混合比混合比 } & $\begin{array}{c}\text { ルチン散 } \\
0\end{array}$ & 1 & 2 \\
\hline $\begin{array}{c}\text { ュランチ } \\
\text { ル顆粒 } \\
0\end{array}$ & $\begin{array}{l}\text { 安息角 } \\
\text { 逃飛 } \\
\text { 分包口ス }\end{array}$ & & $\begin{array}{l}62.0 \\
10.0 \\
5.75\end{array}$ & \\
\hline 1 & $\begin{array}{l}\text { 安息 角 } \\
\text { 逃飛 率 } \\
\text { 分包口 }\end{array}$ & $\begin{array}{c}37.0 \\
1.70 \\
0.07\end{array}$ & $\begin{array}{r}60.0 \\
3.00 \\
4.25\end{array}$ & $\begin{array}{l}61.0 \\
7.00 \\
4.35\end{array}$ \\
\hline 2 & $\begin{array}{l}\text { 安息 角 } \\
\text { 逃飛 犁 } \\
\text { 分包口ス }\end{array}$ & & $\begin{array}{l}59.0 \\
2.35 \\
4.02\end{array}$ & \\
\hline
\end{tabular}

く,これを無視することはできないものがある．特に， 分包口スには混合する散凧の剂形, 剤質が大きく影響を およぼすものと推定できる。

\section{2 唒混合散绪の逃飛率と分包ロスの関係}

測定の結果を表 $2 \sim 6$ 亿示した. 散剂の 2 種混合時の. 逃飛率の変動は, 混合する散剤の物性によって, かなり の違いがある.すなわち物性の大きく異なった散剤を混: 合する場合は, 大体混合比に比例して逃飛率も変動す る. 逃飛率の差の小さい散剤, すなわち同剤形の散剤を 混合する場合も逃飛率は混合比に比例して変動するがそ の変動は少ない，散剤の 2 種混 合 時の 分包ロスの変動 も, 散剤の混合比に比例して分包口スは変動するが, 混. 合する散凧の物性により, 変動の度合いはかなり差があ る.すなわち, 同剤形の散剤混合の場合は分包口スの变 動は少ない，物性の大きく異なった散阏を混合する場合 の分包口スは, 混合比に比例して变化するようである が, 必ずしも混合比と正比例して変化するのではなく, 混合する散凧の物性に大きく影響されることが測定結果 より推定できる，また，混合する散凧の物性により分包: ロスは非常にバラッキが大きい，バラッキの原因と考党 られるのは, 物性の大きく異なるものは分割時に均等に 分割しにくいこと，特に自動分割分包機使用のときは分 割時の振動が激しく，ベルト上でそれぞれの散剤が分難: しやすく, 特に顆粒剤と粉末剤の場合は分離方著しい。 このため分包機のホッパーから分包紙までの落下時の吸. 引ロスのバラッキが大きいのか, あるいは, 分包時の吸 湿, 特に室内の湿度に影響されることが考えられるが, この点に関しては今後検討したいと考えている.

\section{2 程混合散剂の安息角と分包ロスと関係}

測定の結果を表 $2 \sim 6$ に示した。一般的に散剤の 2 種. 
混合時の安息角は，逃飛率と同様に，散剤の混合比に比 例して変動する傾向にある. 安息角の変動は逃乘率より も著しく，混合する散剤の物性によって不定であり， 心 ラッキが大きく，湘定不可能の場合もある.すなわち同 剤形の散剤を混合する場合は, 比較的混合比に比例して 安息角も変動し, 分包口スも比例して変化する㑯向にあ る.物性の大きく異なった散剤（たとえば，顆粒剤と粉 末剤）を混合する場合は, 安息角測定時に測定方法が注 入法であるため, 落下時に顆粒剤と粉末剤がほぼ完全に 分離してしまい, 安息角は結果的には粉末剤の安息角に 近い值を示すことになり，2 種混合散斉の分包口スと安 息角との関係を論ずることはできない. 特にルチン散と コランチル顆粒, 乳酸カルシウムとコランチル顆粒の混 合の場合は, それらの混合物の安息角ではなく、ルチン 散, 乳酸カルシウム単独に近い安息角であることが, 図 4,5 ,表 $5 ， 6$ から推定することができる.したがって 2 種混合散剤の安息角を測定する場合は，注入法測定で は散剤の同剂形の混合物以外は安息角を論ずることは不 可能である. したがって， 2 種混合散凧は, 安息角の変 動にしたがって分包口スは比例して変動する傾向にある が，混合する散剤の物性により大きく差があり，安息角 と分包口スを結びつけて論ずるのは不可能である.

以上の結果から推定されることは，2 種混合散剤の分
包口スは，それぞれ散剤単味で分包した場合の分包口ス のほぼ中間の値を示す。しかし，分包ロスは散剤の混合 比にかならずしも比例するのでなく，混合する散凧の物 性，特に剂形に大きく影䈏を受ける。さらに，2種混合 散剂の逃飛率も混合比にやや比例して变動するが，混合 する散剤の物性に大きく影響をを受ける，さらに，2種 混合散剤の逃飛率も混合比にやや比例して変動するが,

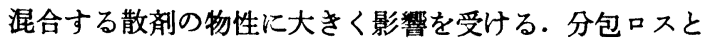
安息角の関係も，同物性・同剂形の散剤の混合物の場合 は, 逃飛率と同樣に混合比にやや比例して安息角も変動 するが，混合する散剤の物性により，かなりのバラッキ があり, 分包ロスと安息角を直接結びつけることは以上 の結果だけでは困難である.この点に関しては今後検討 してゆきたいと思う。

1) 住田他：病院薬学, 1, 155 (1975).

2) 住田他：東海蓃郕師会第 8 回学術大会（1975 年津 市）にて発表.

3) 青木他: 薬凨学, 27, 106 (1967).

4) 青木他: 䊬郕学, 28, 38 (1968).

5) Zenz, F. A. : Petroleum Refiner, 36, 173 (1957).

6) 青木他：薬剤学，27，266 (1967). 